\title{
QUALITY OF WILD BOAR MEAT AND COMMERCIAL PORK
}

\author{
Andréa Fernanda Marchiori; Pedro Eduardo de Felício* \\ Depto. de Tecnologia de Alimentos - UNICAMP/FEA, C.P. 6121 - CEP: 13083-970 - Campinas, SP. \\ *Corresponding author <felicio@fea.unicamp.br>
}

\begin{abstract}
Presently there is a growing interest in the production and marketing of wild boar meat, and to attend a differentiated consumer demand the quality attributes of this product should be well established. To characterize the quality of wild boar meat in comparison to commercial pork, post mortem changes in the longissimus dorsi and semimembranosus muscles were determined by $\mathrm{pH}$ and temperature decline, and color (CIE L* $\left.a^{*} b^{*}\right)$ measurements. Water holding capacity (WHC) was determined by the compression method and the exudate loss (EL) by the drip loss test. Decline in longissimus dorsi muscle pH of wild boar was gradual and in the pork it was faster and more extensive. Temperature differences were observed in some post mortem times, and the lowest values were found in wild boar carcasses. Wild boar meat presented lower values of $\mathrm{L}^{*}$ (brightness) and $\mathrm{b}^{*}$ (yellow color intensity), and higher values of $\mathrm{a}^{*}$ (red color intensity) than pork. The WHC of the wild boar meat was similar to pork, but the EL in female wild boar meat was lower than in pork.
\end{abstract}

Key words: $\mathrm{pH}$, color, drip loss, water holding capacity

\section{QUALIDADE DA CARNE DE JAVALI E DE SUÍNO COMERCIAL}

\begin{abstract}
RESUMO: Atualmente existe no Brasil um interesse crescente na criação e exploração comercial da carne de javali e para atender a uma demanda diferenciada é importante que os atributos qualitativos do produto sejam bem estabelecidos. Com o objetivo de caracterizar a carne de javali nos parâmetros de qualidade e compará-la com a carne suína comercial, as mudanças nos músculosLongissimus dorsieSemimembranosus, no postmortem, foram acompanhadas com medidas de $\mathrm{pH}$, temperatura e cor ( $\left.\mathrm{CIE} \mathrm{L}^{*} \mathrm{a}^{*} \mathrm{~b}^{*}\right)$. A capacidade de retenção de água (CRA) foi determinada pelo método de compressão e a perda de exsudato (PE) pelo teste de "drip loss". A queda de $\mathrm{pH}$ na carne de javali ocorreu de forma gradual, enquanto que noLongissimus dorsi de suíno a diminuição foi mais rápida e mais extensa. Diferenças de temperatura foram verificadas em alguns tempos postmortem, sendo que os menores valores foram encontrados nos javalis. A carne de javali teve valores menores de $L^{*}$ (luminosidade) e b* (intensidade de amarelo) e maiores de $a^{*}$ (intensidade de vermelho) que a carne suína. A CRA da carne dos javalis foi semelhante à da carne suína, mas a PE na carne de javali fêmea foi menor do que na de suíno.

Palavras-chave: $\mathrm{pH}$, cor, perda de exsudato, capacidade de retenção de água
\end{abstract}

\section{INTRODUCTION}

The wild boars raised in Brazil are members of the European wild boar subspecies (Sus scrofa scrofa). However, within different populations of the same species, variations can occur in phenotypic characteristics caused by crosses, gender, age and diet (Giannoni, 1979).

Some reports can be found in the literature on work carried out with wild animals or those resulting from crosses of the wild with swine (Fabbri \& Bergonzini, 1980). These papers are related to metal content in the meat, liver and kidney (Petkov, 1988a), amino acid and protein content (Petkov, 1988b), microbiology (Boers, 1988), pesticide residues in the fat (Zasadowski et al., 1988), chemical composition (Petkov, 1985), fatty acid and lipidic fraction content (Petkov \& Monov, 1985), carcass measurements (Mahendranathan \& Mellish, 1971) and meat quality (Schwaegele et al., 1995).

In view of the scarcity of wild boar research in the national scientific literature, we decided to perform this study with the objective of characterizing the meat of this genetic group as to its physical and chemical properties (decline in $\mathrm{pH}$, water holding capacity and exudate loss), decline in temperature and instrumental color analysis, using swine meat as a reference for comparisons.

\section{MATERIAL AND METHODS}

The research was carried out at a slaughterhouse-cold-storage plant under Federal Inspection Service, located in Amparo, S.P. Brazil, and the laboratory evaluation at - UNICAMP, Campinas, SP. The $\mathrm{pH}$, temperature and color analyses $\left(\mathrm{L}^{*} \mathrm{a}^{*} \mathrm{~b}^{*}\right)$ were performed in the muscles Longissimus dorsi (LD) and Semimembranosus (SM) of 58 wild boar (males and females) and 15 swine specimens. The determination of exudate loss and the analysis of water holding capacity were performed in samples from the LD muscle of 17 wild boars (10 males and 7 females, with age between 159 and 816 days) and 15 swine. 


\section{Animals}

In this study, commercial wild boar (Sus scrofa) males and females, were evaluated, as well as commercial swine, which were considered as a comparison standard against the results obtained with wild boars.

The swine, resulting from crosses between Landrace, Large White and Pietran breeds, were raised in a confinement system and weighed between 80 and $122 \mathrm{~kg}$ ( 130 days of age, on average) and the wild boars, raised in a semiconfinement system, weighed from 20 to $145 \mathrm{~kg}$.

\section{Slaughter}

Slaughter was performed according to the Federal Inspection Regulation (Brazil, 1980). The distance wild boars were transported was approximately $170 \mathrm{~km}$, in 3 hours, while for swine $800 \mathrm{~m}$, in 10 minutes. The hydric diet time was 15 hours minimum. Stunning was made by electric shocks (Hog Stunner, model HS380 ) of $420 \mathrm{~V}$ and $1.5 \mathrm{~A}$, for both groups. Immediately following stunning, the animals were bled on a table. Ten minutes after bleeding, they were scalded $\left(60^{\circ} \mathrm{C}\right.$ during approximately 5 minutes). Then the animals were flayed, eviscerated and submitted to carcass and viscera inspection, split in two carcass halves.

\section{$\mathrm{pH}$, Temperature and Color}

The post mortem alterations in $\mathrm{pH}$ and temperature were measured in the LD and SM muscles, $1 ; 2 ; 6 ; 12 ; 24$; and 48 hours after slaughter, using portable METTLER-TOLEDO type MP 125 potentiometer, with a glass electrode and a temperature probe, which were inserted in the central portion of the muscles from the right half of the carcass. The first measurement was made at the end of the slaughter line, and the additional measurements were made with the carcasses stored in a cold-storage chamber (temperature from $0^{\circ}$ to $2^{\circ} \mathrm{C}$ ).

Meat color was evaluated 24 and 48 hours post mortem on the transversal section of the LD muscle at the point of the $10^{\text {th }}$ thoracic vertebra and on the surface of the SM muscle by using a portable Miniscan XE colorimeter, which characterizes color based on parameters $L^{*}$ (lightness), $a^{*}$ (red color intensity) and $b^{*}$ (yellow color intensity) of the CIE - "Comission Internationale de L'Eclairage" system (Hutchings, 1994). The observer's reading angle was $10^{\circ}$, illuminant D 65 , specular reflectance included, with calibration of standard white nr. VM 03500, V ( $X=80.3 \quad Y=85.1 \quad Z=91.0)$ and black.

\section{Exudate Loss (EL)}

Twenty four hours post mortem, duplicate samples were taken from the LD muscle, at the point of the 10th rib, of each right half carcass of wild boars and swine, weighing approximately 100 grams, which were carefully cleaned and weighed on a semi-analytical balance. Then, they were involved in a reticulated plastic wrapping and suspended inside a plastic bag. The set remained hung in a cold-storage chamber at $2^{\circ} \mathrm{C}$ in such a way that the exudate would not get in contact with the meat. After 48 hours samples were removed and the surface moisture was eliminated with absorbing paper before weighing. The result was expressed as weight loss in $\mathrm{g} / 100 \mathrm{~g}$ of the original weight (Honikel, 1987, adapted by Silveira, 1997).

\section{Water Holding Capacity}

The water holding capacity (WHC) was determined in samples of approximately $500 \mathrm{mg}$, in two replicates, from the LD muscle of wild boars and swine by applying a pressure of $3450 \mathrm{kPa}$, for 1 minute), according to the Grau \& Hamm's compression method, cited by Wierbicki \& Deatherage (1958). Results express the differences between water halo areas and the compressed sample with differences adjusted to $500 \mathrm{mg}$.

\section{Statistical Analysis}

Data obtained were submitted to analysis of variance (ANOVA) and the differences between the groups under study were analyzed using the t or Tukey tests for comparison of means $(P<0.05)$, by using the Statistica software package (StatSoft, 1995).

\section{RESULTS AND DISCUSSION}

\section{$\mathrm{pH}$ decline curve in the muscle}

The $\mathrm{pH}$ value means obtained in the sampling periods $(1 ; 2 ; 6 ; 12 ; 24$; and 48 hours) after slaughter in the LD and SM muscles of wild boar and swine are shown in Table 1.

For wild boar meat the initial $\mathrm{pH}(1 \mathrm{~h})$ was 6.18 for LD and 6.22 for SM, with a gradual decrease down to the final $\mathrm{pH}$ of 5.46 for LD and 5.47 for SM. For pork, the initial $\mathrm{pH}$ (1h) was 6.09 for LD and 6.31 for SM, a slightly faster and more extensive decrease having been observed until the final $\mathrm{pH}$ of 5.32 for LD and 5.34 for SM.

The $\mathrm{pH}$ decline curves for the genetic groups of wild boar ( $n=58)$ and swine $(n=15)$ [for muscles LD and $\mathrm{SM}]$ can be observed in Figure 1.

The decline in $\mathrm{pH}$ following death caused by lactic acid accumulation is one of the most remarkable factors of muscle transformation in meat, with crucial importance in its future quality and derivative products.

The $\mathrm{pH}$ values found in this experiment for swine were higher than those found by Silveira (1997) who, studying the effect of electrical insensibilization applied manually and automatically on the quality of pork, observed for manual insensibilization in measurements made 1; 2; and 24 hours post mortem, pH values of 5.68; 5.52 and 5.44 , respectively for LD of castrated males, and 5.59; 5.47 and 5.42, for LD of females, respectively. Values observed in SM muscles for the same post mortem times were 5.65; 5.56 and 5.44, for males, and 5.66; 5.49 and 5.45 , for females, respectively. 
Pardi et al. (1993) reported that for swine, a $\mathrm{pH}=7$ in the live muscle drops to 5.6-5.7, 6-7 hours post mortem, reaching a final $\mathrm{pH}$ of $5.3-5.7,24$ hours post mortem, and that the decrease in $\mathrm{pH}$ is not uniform for all animals, as it can rapidly fall to 5.4-5.5 in the first hour post mortem until it reaches $\mathrm{pH}$ 5.3-5.6. The results obtained in this study, 24 hours post mortem for both genetic groups are within the normality interval pointed out by these authors.

The fast reduction in $\mathrm{pH}$ immediately after death, while meat temperature is still maintained high, results in PSE (Pale, Soft and Exudative) meat. According to Troeger \& Woltersdorf (1987), the main defects pointed toward pork meat were those related to the PSE anomaly. The values determined in this study did not reveal a sudden decline in $\mathrm{pH}$ (Table 1 and Figure 1).

The mean $\mathrm{pH}$ values in the first post mortem hour $\left(\mathrm{pH}_{1}\right)$, for both genetic groups, fall outside the range considered critical (LD, $\mathrm{pH}_{1}<5.6$ and $\left.\mathrm{SM}, \mathrm{pH}_{1}<5.8\right)$ for developing PSE meat (Woltersdorf \& Troeger, quoted by Silveira, 1997) and are also below the critical limit $\left(\mathrm{pH}_{1}>6.4\right)$ for DFD (Dark, Firm and Dry) meat, according to Barton-Gade, quoted by Silveira (1997). The 24 hour $\mathrm{pH}$ mean for LD in wild boar $(5.57 \pm 0.10)$ can be considered normal, while the mean value for LD in swine $(5.46 \pm 0.13)$ was very close to the normality range $(\mathrm{pH}=5.49-5.77)$ mentioned by Wal et al. (1988).

The smallest $\mathrm{pH}$ values were found in swine. Differences $(P<0.05)$ in $\mathrm{pH}$ between wild boar and pork occurred at times 2; $12 ; 24$; and 48 hours post mortem in the LD muscle, and at 48 hours post mortem in the SM muscle.

This difference could be associated to a higher resistance of wild boars to stress, as reported by Knorr et al. (1994) in a DNA study of swine of different origins by means of allele $C$ (associated with stress resistance) frequency. The authors observed the following frequencies: 0.0 for Belgian Landrace, 0.01 for Pietrain, 0.54 for German Landrace, 0.86 for German Landrace (maternal line), 0.91 for Schwaebisch-Haellisches, 0.95 for European Wild Boar and 0.99 for Large White.

\section{Carcass temperature decline curves}

The temperature value means obtained during the sampling period $(1 ; 2 ; 6 ; 12 ; 24$; and 48 hours $)$ after slaughter in LD and SM muscles of wild boar and pork are shown in Table 2.

The initial temperature for wild boar carcass (1h) was $30.2^{\circ} \mathrm{C}$ for the $\mathrm{LD}$ muscle, and $32.9^{\circ} \mathrm{C}$ for SM. A reduction in mean temperature occurred after the first measurement, of $7.3^{\circ} \mathrm{C}\left(2 \mathrm{~h}=22.9^{\circ} \mathrm{C}\right)$ in $\mathrm{LD}$, and of $6.9^{\circ} \mathrm{C}$ $\left(2 \mathrm{~h}=26.0^{\circ} \mathrm{C}\right)$ in $\mathrm{SM}$. Temperature reached to $9.5^{\circ} \mathrm{C}$ for LD and $10.2^{\circ} \mathrm{C}$ for $\mathrm{SM}, 12$ hours post mortem. At 48 hours, final temperatures of $4.3^{\circ}$ and $4.8^{\circ} \mathrm{C}$ were observed for LD and SM muscles, respectively.

The initial temperature for swine carcass (1h) was $34.1^{\circ} \mathrm{C}$ for $\mathrm{LD}$, and $34.3^{\circ} \mathrm{C}$ for $\mathrm{SM}$. A reduction occurred after the first measurement, on average $6.3^{\circ} \mathrm{C}$ $\left(2 \mathrm{~h}=27.8^{\circ} \mathrm{C}\right)$ for $\mathrm{LD}$, and $6.8^{\circ} \mathrm{C}\left(2 \mathrm{~h}=27.5^{\circ} \mathrm{C}\right)$ for $\mathrm{SM}$. Temperature reached to $13.2^{\circ} \mathrm{C}$ for $\mathrm{LD}$ and $12.7^{\circ} \mathrm{C}$ for SM, 12 hours post mortem. After 48 hours, temperatures observed were $4.0^{\circ} \mathrm{C}$ and $5.0^{\circ} \mathrm{C}$ for muscles $\mathrm{LD}$ and $\mathrm{SM}$, respectively.

The temperature decline curves obtained for LD and SM muscles in wild boar $(n=58)$ and swine $(n=15)$, at times $1 ; 2 ; 6 ; 12 ; 24$; and 48 hours post mortem can be observed in Figure 2.

Differences in temperature between wild boars and swine were significant $(P<0.05)$ by the t test, at times 1; 2; 6; and 12 hours post mortem for LD muscle, and times 1 and 12 hours for SM muscle. The highest temperature values were observed for swine, which belonged to the highest carcass weights.

Temperature values in the muscles obtained in this experiment are near to those found by Silveira (1997) for pork meat (LD and SM, 1 and $2 \mathrm{~h}$ post mortem, respectivly) from manually insensibilized animals.

Silveira (1997) points out that a faster chilling of

Table 1 - Mean $\mathrm{pH}$ values at various post mortem times for muscles Longissimus dorsi (LD) and Semimembranosus (SM) of wild boar and swine.

\begin{tabular}{lccc}
\hline \multirow{2}{*}{ Time } & \multirow{2}{*}{ Muscle } & \multicolumn{2}{c}{ Mean \pm standard deviation } \\
\cline { 2 - 4 } & & Wild boar $(\mathrm{n}=58)$ & Swine $(\mathrm{n}=15)$ \\
\hline \multirow{2}{*}{$1 \mathrm{~h}$} & LD & $6.18 \pm 0.25 \mathrm{a}$ & $6.09 \pm 0.19 \mathrm{a}$ \\
& SM & $6.22 \pm 0.21 \mathrm{a}$ & $6.31 \pm 0.23 \mathrm{a}$ \\
$2 \mathrm{~h}$ & LD & $5.97 \pm 0.18 \mathrm{a}$ & $5.79 \pm 0.20 \mathrm{~b}$ \\
& SM & $6.00 \pm 0.18 \mathrm{a}$ & $5.94 \pm 0.15 \mathrm{a}$ \\
$6 \mathrm{~h}$ & LD & $5.75 \pm 0.14 \mathrm{a}$ & $5.67 \pm 0.14 \mathrm{a}$ \\
& SM & $5.78 \pm 0.15 \mathrm{a}$ & $5.77 \pm 0.13 \mathrm{a}$ \\
$12 \mathrm{~h}$ & LD & $5.64 \pm 0.11 \mathrm{a}$ & $5.56 \pm 0.16 \mathrm{~b}$ \\
& SM & $5.68 \pm 0.14 \mathrm{a}$ & $5.69 \pm 0.14 \mathrm{a}$ \\
& LD & $5.57 \pm 0.10 \mathrm{a}$ & $5.46 \pm 0.13 \mathrm{~b}$ \\
& SM & $5.60 \pm 0.12 \mathrm{a}$ & $5.57 \pm 0.13 \mathrm{a}$ \\
$48 \mathrm{~h}$ & LD & $5.46 \pm 0.14 \mathrm{a}$ & $5.32 \pm 0.10 \mathrm{~b}$ \\
& SM & $5.47 \pm 0.15 \mathrm{a}$ & $5.34 \pm 0.10 \mathrm{~b}$ \\
\hline
\end{tabular}

a, bean values of the same row with common letters do not present difference $(P>0.05)$ by the test.

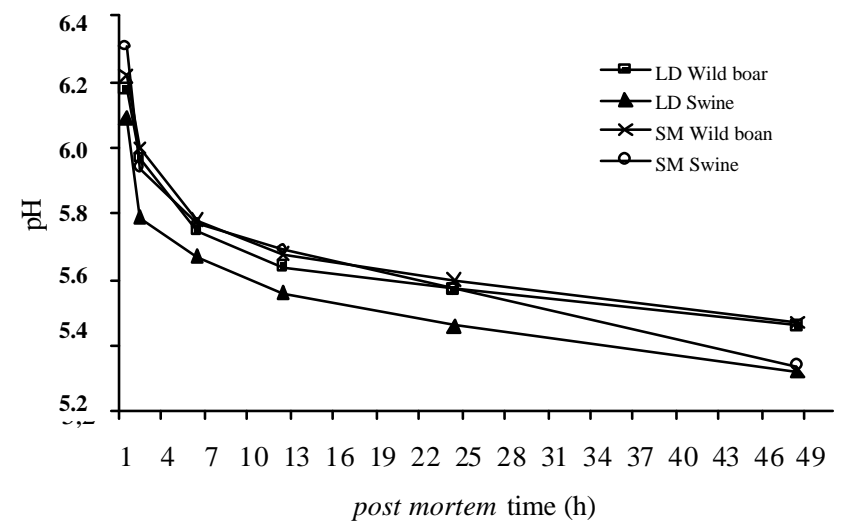

Figure 1 - $\mathrm{pH}$ decline at various post mortem times for Longissimus dorsi (LD) and Semimembranosus (SM) muscles of wild boar $(n=58)$ and swine $(n=15)$. 
Table 2 - Mean temperature values at various post mortem times for muscles Longissimus dorsi (LD) and Semimembranosus (SM) of wild boar and swine.

\begin{tabular}{|c|c|c|c|}
\hline \multirow{2}{*}{ Time } & \multirow{2}{*}{ Muscle } & \multicolumn{2}{|c|}{ Mean \pm standard deviation } \\
\hline & & Wild boar $(n=58)$ & Swine $(n=15)$ \\
\hline \multirow{2}{*}{$1 \mathrm{~h}$} & LD & $30.2 \pm 3.1 \mathrm{~b}$ & $34.1 \pm 2.1 \mathrm{a}$ \\
\hline & SM & $32.9 \pm 1.7 b$ & $34.3 \pm 2.0 \mathrm{a}$ \\
\hline \multirow{2}{*}{$2 \mathrm{~h}$} & LD & $22.9 \pm 4.9 b$ & $27.8 \pm 1.5 a$ \\
\hline & SM & $26.0 \pm 3.8 \mathrm{a}$ & $27.5 \pm 1.5 a$ \\
\hline \multirow{2}{*}{$6 \mathrm{~h}$} & LD & $12.4 \pm 3.2 b$ & $15.4 \pm 1.6 \mathrm{a}$ \\
\hline & SM & $13.3 \pm 2.6 a$ & $14.4 \pm 2.3 a$ \\
\hline \multirow{2}{*}{$12 \mathrm{~h}$} & LD & $9.5 \pm 2.0 b$ & $13.2 \pm 1.0 \mathrm{a}$ \\
\hline & SM & $10.2 \pm 2.4 b$ & $12.7 \pm 1.3 \mathrm{a}$ \\
\hline \multirow{2}{*}{$24 \mathrm{~h}$} & LD & $5.4 \pm 0.5 a$ & $5.3 \pm 0.6 a$ \\
\hline & SM & $5.4 \pm 0.4 a$ & $5.1 \pm 0.8 a$ \\
\hline $48 \mathrm{~h}$ & LD & $4.3 \pm 0.6 a$ & $4.0 \pm 0.8 a$ \\
\hline
\end{tabular}

a, bMean values of the same row with common letters do not present difference $(P>0.05)$ by the t test.

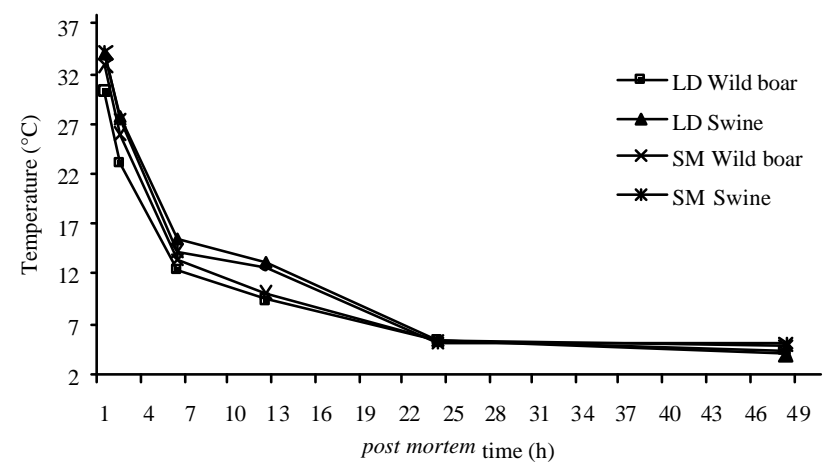

Figure 2 - Temperature decline curve at various post mortem times for Longissimus dorsi(LD) and Semimembranosus (SM) muscles of wild boar $(n=58)$ and swine $(n=15)$.

the carcass and, especially, of commercial cuts, favor a reduction of the incidence of PSE meat, in addition to contributing toward a better microbiological quality.

\section{Color analysis}

Color values $\left(L^{*} a^{*} b^{*}\right)$ found for $L D$ and SM muscles for wild boar $(n=58)$ and swine $(n=15), 24$ and 48 hours post mortem, are shown in Table 3 .

Pork loin with $L^{*}$ values between 49 and 60 would have good visual aspect according to the criteria utilized by the Meat and Livestock Commission in relation to meat quality (Warriss \& Brown, 1995). The results obtained in this experiment for wild boar and pork are within this range.

However, according to the classification proposed by Wal et al. (1988), the color values $\left(L^{*} a^{*} b^{*}\right) 24$ hours post mortem, for swine LD muscle $\left(\mathrm{L}^{*}{ }_{\mathrm{L}}=58.6 \pm 2.2\right.$, $\left.\mathrm{a}^{*}{ }^{\mathrm{D}}=5.2 \pm 1.2 \mathrm{e} \mathrm{b}^{*}{ }_{\mathrm{L}}=14.5 \pm 0.8\right)$ fall within a range considered as critical $\left(L^{*}=57.1-61.3, a^{*}=6.2-8.6\right.$ and $\left.b^{*}=15.2-16.8\right)$ for PSE, because the $L^{*}$ value in this case indicates paleness. In contrast, the means observed for wild boar meat $\left(\mathrm{L}^{*}{ }_{\mathrm{LD}}=51.3 \pm 3.1, \mathrm{a}_{\mathrm{LD}}^{*}=7.9 \pm 1.3\right.$ and $\mathrm{b}^{*}$ $=13.2 \pm 1.3)$ are compatible with the ranges for normal meat $\left(L^{*}=52 \cdot 2-54.8, a^{*}=5 \cdot 1-7.5\right.$ and $\left.b^{*}=12 \cdot 9-14.5\right)$ suggested by them.
The $L^{*} a^{*} b^{*}$ means for SM muscle surface in swine, 24 hours post mortem $\left(\mathrm{L}^{*}{ }_{\mathrm{SM}}=54.9 \pm 3.8, \mathrm{a}^{*}{ }_{\mathrm{SM}}=6.9 \pm\right.$ 1.3) are similar to values reported by Silveira (1997) for swine. However, the means for wild boar meat $\left(\mathrm{L}^{*}{ }_{\mathrm{SM}}=50.4\right.$ $\left.\pm 4.7, \mathrm{a}_{\mathrm{SM}}^{*}=8.3 \pm 2.1\right)$ denote a darker coloration, with greater intensity of red. The $b^{*}$ values (yellow intensity), both for swine and wild boars, are higher than those found by Silveira (1997) for pork meat, in the same muscle and time post mortem; the cited author utilized, however a Minolta CR200b colorimeter operating with a different light source and observation angle than the Miniscan XE colorimeter utilized in this research.

The means differ $(P<0.05)$ between the two genetic groups under study in all evaluated color parameters, for LD and SM muscles, and the two measuring times (24 and 48 hours post mortem). The greatest lightness $\left(L^{*}\right)$ and yellow color intensity $\left(b^{*}\right)$ values were obtained for commercial pork, and the greatest red color intensity $\left(\mathrm{a}^{\star}\right)$ was obtained for wild boar meat.

These values give to the wild boar meat a darker coloration as compared to pork, as also verified by Schwaegele et al. (1995). According to Hedrick et al. (1994), wild animals have darker muscles than domestic animals due to a higher concentration of myoglobin as a result of their intense physical activity.

The differences in meat color between genetic groups can be partially attributed to a slower decline in $\mathrm{pH}$ and a faster decline of the temperature of wild boar meat.

\section{Exudate loss and water holding capacity}

The mean results for exudate loss (EL), and water holding capacity (WHC), for LD muscle of female wild boar, male wild boar and swine can be observed in Table 4.

The greatest exudate losses $(P<0.05)$ were verified for LD muscle of swine as compared to female wild boars; however, the difference of one percent between swine and male wild boars was non-significant $(P>0.05)$.

Schwaegele et al. (1995) observed that the smallest EL values $(P<0.05)$ were found for wild boar meat, without making any reference to gender.

The EL values for pork $\left(5.53 \pm 1.24 \mathrm{~g}_{\left.100 \mathrm{~g}^{-1}\right)}\right.$ found in this experiment are similar to those reported by Silveira (1997) for swine scalded in a tank, i.e., $5.48 \%$ for conventional boning and $5.43 \%$ for hot boning, and greater than those observed by Sather et al. (1991), 3.8\%, and by Rosa et al. (2001), 3.64\%, for swine LD muscle.

The differences were non-significant $(P>0.05)$ for WHC between the groups of female wild boars, male wild boars, and swine. The 24 hour post mortem WHC for swine meat observed by Pinheiro et al. (1987) was $23.99 \mathrm{~cm}^{2}$ for halothane-non-sensitive individuals, therefore higher than the values found in this study, which revealed smaller WHCs. 
Table 3 - Color values ( $\mathrm{L}^{*} \mathrm{a}^{*} \mathrm{~b}^{*}$ ) of Longissimus dorsi (LD) and Semimembranosus (SM) muscles of wild boar and swine.

\begin{tabular}{|c|c|c|c|}
\hline \multirow{2}{*}{ Post mortem time } & \multirow{2}{*}{ Parameter } & \multicolumn{2}{|c|}{ Mean \pm standard deviation } \\
\hline & & Wild boar $(n=58)$ & Swine $(n=15)$ \\
\hline \multirow{6}{*}{$24 \mathrm{~h}$} & $L^{*} L D$ & $51.30 \pm 3.09 b$ & $58.63 \pm 2.15 a$ \\
\hline & $L^{*} S M$ & $50.38 \pm 4.68 b$ & $54.92 \pm 3.84 \mathrm{a}$ \\
\hline & $a^{*} L D$ & $7.94 \pm 1.31 \mathrm{a}$ & $5.16 \pm 1.20 \mathrm{~b}$ \\
\hline & $a^{*} S M$ & $8.30 \pm 2.12 a$ & $6.88 \pm 1.27 b$ \\
\hline & $b^{*} L D$ & $13.24 \pm 1.26 b$ & $14.47 \pm 0.82 \mathrm{a}$ \\
\hline & $b^{*} S M$ & $10.92 \pm 1.67 b$ & $13.21 \pm 1.57 \mathrm{a}$ \\
\hline \multirow{6}{*}{$48 h$} & $L^{*} L D$ & $49.82 \pm 3.48 \mathrm{~b}$ & $59.00 \pm 2.72 \mathrm{a}$ \\
\hline & $L^{*} S M$ & $51.42 \pm 2.70 \mathrm{~b}$ & $54.56 \pm 5.90 a$ \\
\hline & $a^{*} L D$ & $9.50 \pm 1.46 \mathrm{a}$ & $7.65 \pm 1.43 b$ \\
\hline & $a^{*} S M$ & $9.06 \pm 1.66 \mathrm{a}$ & $7.96 \pm 1.90 b$ \\
\hline & $b^{*} L D$ & $12.99 \pm 1.33 b$ & $16.38 \pm 0.79 a$ \\
\hline & $b^{*} S M$ & $13.10 \pm 2.20 b$ & $14.68 \pm 1.64 \mathrm{a}$ \\
\hline
\end{tabular}

a, bean values of the same row with common letters do not present difference $(P>0.05)$ by the t test.

Table 4 - Exudate loss (EL) and Water Holding Capacity (WHC) in Longissimus dorsi muscle of wild boar and swine.

\begin{tabular}{lccc}
\hline & \multicolumn{3}{c}{ Mean \pm standard deviation } \\
\cline { 2 - 4 } & Female wild boar $(\mathrm{n}=7)$ & Male wild boar $(\mathrm{n}=10)$ & Swine $(\mathrm{n}=15)$ \\
\hline $\mathrm{WHC},\left(\mathrm{cm}^{2}\right)$ & $20.15 \pm 5.19 \mathrm{a}$ & $20.75 \pm 5.62 \mathrm{a}$ & $21.97 \pm 1.95 \mathrm{a}$ \\
$\mathrm{EL},\left(\mathrm{g} 100 \mathrm{~g}^{-1}\right)$ & $3.42 \pm 0.77 \mathrm{~b}$ & $4.55 \pm 1.64 \mathrm{ab}$ & $5.53 \pm 1.24 \mathrm{a}$ \\
\hline
\end{tabular}

a, bean values of the same row with common letters do not present difference $(P>0.05)$ by the Tukey test.

\section{CONCLUSIONS}

From a commercial and processing standpoint, wild boar meat has advantages over pork, rendered as a more intense red coloration and, specifically in females, as smaller exudate losses in the drip loss test. These differences are related to the slower and less extensive decline in $\mathrm{pH}$ and to a faster decline in temperature, which can be explained by the genetic group, management and feeding of wild boars, resulting in older and less heavy animals at slaughter age.

\section{REFERENCES}

BOERS, R.H. Intrinsic and extrinsic factors in relation to the microbiological quality of vacuum packaged fresh meat. Voedingsmiddelentechnologie, v.21, p.55-57, 1988.

BRASIL. Regulamento da inspeção industrial e sanitaria de produtos de origem animal. Decreto 30691 de 29.03.52, alterado pelo decreto 1255 de 25.06.62. Ministério da Agricultura, Brasília D.F., 1980, 166p.

FABBRI, R.; BERGONZINI, E. Crossing of wild boars with purebred sows. Annalidell'Instituto-Sperimentale-per-la-Zootecnia, v.13, p.187-199, 1980.

GIANNONI, M.A. Evolução cariotípica na família Suidae. Jaboticabal, 1979. 226p. Tese (Livre Docência) - Faculdade de Ciências Agrárias e Veterinária, Universidade Estadual Paulista "Julio de Mesquita Filho".

HEDRICK, H.B.; ABERLE, E.D.; FORREST, J.C.; JUDGE, M.; MERKEL, R.A Properties of fresh meat. In: PRINCIPLES of meat science. 3.ed. Kendall: Hunt Publishing Company, 1994. cap.6, p.123-131.

HUTCHINGS, J.B. Instrumental specification. In: FOOD colour appearance. New York: Chapman \& Hall, 1994. cap.7, p.199-237.

KNORR, C.; SCHWILLE, M.; MOSER, G.; MUELLER, E.; BARTENSCHLAGER, H.; GELDERMANN, H. Calcium-release-channel genotypes in several pig populations- associations with halothane and CK reactions. Journal of Animal Breeding and Genetics, v.111, p.242-252, 1994.

MAHENDRANATHAN, T.; MELLISH, K.S. Some observations on the carcass of the wild pig and wild pig crosses. Malaysian Veterinary Journal, v.5, p.22-24, 1971.

PARDI, C.P.; SANTOS, I.F.; SOUZA, E.R.; PARDI, H.S. Fundamentos da ciência da carne. In: CIÊNCIA higiêne e técnologia da carne. Goiânia: EDUFF, 1993. v.1, cap.2, p.35-127.
PETKOV, R. Chemical composition of wild boar meat. Veterinarnomeditsinski-Nauki, v.22, p.53-57, 1985.

PETKOV, R. Macro and microelement contend of game meat. KhramitelnaPromishlenost, v.37, p.35-36, 1988a.

PETKOV, R. Amino acid contents of meat of wild and domestic animals and birds. Khramitelna-Promishlenost, v.37, p.14-16, 1988b.

PETKOV, R.; MONOV, G. Contend of fatt acids in lipid fraction of wild boar meat. Veterinarnomeditsinski-Nauki, v.22, p.54-58, 1985.

PINHEIRO, M.G.; GIANNONI, M.A.; FELÍCIO, P.E.; CASTRO JR., F.G. Características de carcaça e da carne de suínos sensíveis e não sensíveis ao halotano. Boletim Indústria Animal, v.44, p.81-92, 1987.

ROSA, A.F.; SOBRAL, P.J.A.; LIMA, C.G.; GOMES, J.D.F. Determinação das características físico-químicas da carne de suínos em fase de crescimento. Revista TeC Carnes, v.3, p.13-18, 2001.

SATHER, A.P.; MURRAY, A.C.; ZAWADSKI, S.M.; JOHNSON, P. The effect the halotane gene on pork production and meat quality of pigs reared under commercial conditions. Canadian Journal of Animal Science, v.71, p.956-967, 1991.

SCHWAEGELE, F.; RAAB, H.J.; KROECKEL, L. Meat quality of wild boars. IChanges post mortem in muscles of wild boar after hunting. Fleischwirtschaft, v.75, p.135-140, 157, 1995.

SILVEIRA, E.T.F. Técnicas de abate e seus efeitos na qualidade da carne suína. Campinas, 1997. 247p. Tese (Doutorado) - Universidade Estadual de Campinas.

STATSOFT, Inc. (1995). Statistica for Windows [Computer program manual]. Tulsa, OK: StatSoft, Inc., 2325 East $13^{\text {th }}$ Street, Tulsa, OK 74104.

TROEGER, K.; WOLTERSDORF, W. Mikrobielle Kontamination von schweineschalachtkörpern durch brühwasser uber das Gefasystem. Fleischwirtschaft, v.67, p.857-860, 1987.

WAL, P.G. Van der; BLINK, A.H.; MERKUS, G.S.M. Differences in quality characteristics of normal, PSE and DFD pork. Meat Sience, v.24, p.7984, 1988.

WARRISS, P.D.; BROWN, S.N. The relationship between reflectance (EEL value) and colour $\left(\mathrm{L}^{*}-\right)$ in pork loins. Animal Science, v.61, p.145-147, 1995.

WIERBICKI, E.; DEATHERAGE, F.E. Determination of water- holding capacity of fresh meats. Agricultural and Food Chemistry, v.6, p.387-392, 1958

ZASADOWSKI, A.; AMAROWICZ, R.; TERLECKA, A. Residues of polychlorinated pesticides in the fat and brain of game (wild boar, roedeer, stags) from the Warmia-Mazuria region. Bromatologia-i-ChemiaToksykologiczna, v.21, p.125-130, 1988.

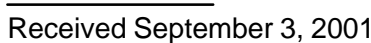

